\title{
Rusya İmparatorluğu Dönemi Tarih Yazımında Peçenekler*
}

\section{Pechenegs in the Historiography of the Russian Empire}

\author{
Muallâ Uydu Yücel' 무
}

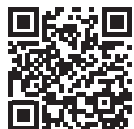

*Bu çalıșma "Rusya İmparatorluğu Dönem Tarih Yazımında Peçenekler", PiESS, 21-23 Eylül 2018, Kiev/Ukrayna'da sözlü sunulan ve "Pechenegs in the Historiography of the Russian Empire", JiEES 2018, Ukranie/ Kyiv, s.207-224'de yayınlanan makalenin genişletilmiş Türkçesidir

'Sorumlu yazar/Corresponding author: Muallâ Uydu Yücel (Prof. Dr.), İstanbul Üniversitesi, Edebiyat Fakültesi, Tarih Bölümü, İstanbul, Türkiye. E-posta: muallauyduyucel@gmail.com ORCID: 0000-0002-1595-2106

Başvuru/Submitted: 02.02 .2021 Revizyon Talebi/Revision Requested: 00.00 .0000

Son Revizyon/Last Revision Received:

00.00 .0000

Kabul/Accepted: 20.02.2021

Atıf/Citation: Uydu Yucel, Mualla, “Rusya İmparatorluğu Dönemi Tarih Yazımında Peçenekler", Güneydoğu Avrupa Araştırmaları Dergisi, 36 (2021), s. 97-117 https://doi.org/10.26650/gaad.872978

\section{öz}

Karadeniz' in kuzeyi ile Doğu Avrupa ve Balkanlarda önemli siyasi ve kültürel varlık gösteren Peçeneklere dair ilk özel çalışmalar Rusya İmparatorluğu döneminin sonlarına doğru 1872 yılında V.G. Vasilyevskiy ve 1884 yilında P.V. Golubovskiy tarafından yapıımıştır. Vasilyevskiy bugün dahi üzerine çıkılamayan "Bizans ve Peçenekler" adlı çalışmasında Peçeneklerin Bizans'a yaşattıklarını tüm teferruatı ile ortaya koyarken; Golubovskiy Peçeneklerin yaşadıkları coğrafya ile siyasi tarihlerinden özellikle de Ruslar ile olan ilişkilerinden bahsetmiştir. Bu çalışmamızda her iki yazarın eserlerinde Peçenekleri nasıl anlattıklarını ortaya koymaya çalışacağız. Bu iki bilim insanın ve sonrasında yapılan çalışmalarda dağınık yaşadıkları için "bir devlet teşekkülü içerisinde yer alamayan" denilerek devlet kurmadıkları söylenen Peçenekler gerçekten de bir devlet kurmamışlar mıdır? Yoksa bu düşünce Rus tarihçilerinin yazımından mı kaynaklanmıştır? Bunun üzerinde duracağız. 19. yüzyıl boyunca devam eden yazımda Peçeneklerin daha çok siyasi tarihleri ile ilgili bilgiler verilmekte, onların Bulgar Devletinin yıkılmasından sonra ortaya çıkan boşluğu doldurdukları ve 11. ve 12. yüzyılda Bizans yönetimi için, Asya'daki kardeşleri Selçuk Türkleri kadar korkunç düşman oldukları vurgulanmaktadır. Bu dönem yazarları Birinci Haçlı Seferinin sebeplerinden birini de Peçeneklerin Balkanlardan Bizans'ı sıkıştırmaları olarak göstermektedirler. Peçenekler 896 yilında geldikleri Karadeniz'in kuzeyinde Doğu Slavyan boyları ile siyasi ilişkiler kurmuşlardır. Rus yıllıkları bu ilişkileri daha çok efsaneler üzerinden vermeyi uygun bulmuşlardır. Bu efsanelerde Peçenekler yenilmesi çok güç bir millet olarak verilmişlerdir. 0 sırada Hazarların idaresi altında yaşayan bazı Doğu Slavyan boyları, yine güçlü bir Türk boyu ile mücadele etmek yerine ortak menfaatlerde birlikte hareket etmeyi tercih etmişlerdir. Doğu Slavları ve bazı kavimler birleşerek bir millet teşekkülü içerisinde yer almışlar ve Rus adı ile ortaya çıkarak Kiyev Knyazlığını kurmuşlardır. Bilindiği üzere bu Knyazlığın kurulmasında Hazarlar etkili olmuşlardır. Hazarlardan sonra arka arkaya, Peçenek, Uz ve Kuman/Kıpçak Türk boyları ile karşılaşan ve onların sürekli saldırılarına maruz kalan bu Knyazlığın tarih yazımında araştırıcılar bu Türk boylarına 
kanaatimizce "devlet" kurdurmamışlardır. 0 yüzden de bizde bugün kendi tarih yazımında onları anlatırken bu ifadeyi kullanmaktayız.

Anahtar Kelimeler: Peçenekler, Bizans, Hazarlar, Slavlar, Tarih Yazımı, Rusya İmparatorluğu

\begin{abstract}
The first studies on the Pechenegs, who had an important presence in the north of the Black Sea, eastern Europe and the Balkans, were carried out by V. G. Vasilyevskiy 1872 towards the end of the Russian Empire period and continued with P. Golubovskiy (in 1884). In his work "Byzantium and Pechenegs", Vasilyevskiy revealed the relations of the Pechenegs with Byzantine with in detail. Golubovskiy mentioned the Pechenegs in terms of their geography and political history, especially their relations with Russians. We will mention this in this work, we will try to show how both authors describe the Pechenegs in their works. Also, did the Pechenegs, who were told that they did not establish a state by saying "they can not take part in a state organization" because they lived scattered in Turkish history, not really establish a state? Or is this thought originated from the writing of Russian historians?

In the historiography that continued throughout the 19th century, more information is given about the political history of the Pechenegs and they fill the gap that arose after the collapse of the Bulgarian State and emphasize that, for the Byzantine rule in the 11th and 12th centuries, their brothers in Asia were as terrible enemies as the Saldjūk Turks. The authors of this period also showed that one of the causes of the First Crusade was the Pechenegs' compression of Byzantium from the Balkans.. The Pechenegs established political relations with the eastern Slavicans in the north of the Black Sea in 896. Russian annals have found it appropriate to give these relationships mostly through legends.. In these myths the Pechenegs were given as a very difficult nation to defeat. At the time, some Eastern Slavian dwellers living under the Khazars' ruling preferred to act together in common interests, instead of fighting a strong Turkish tribe. Eastern Slavs and some tribes joined together as a nation, and they emerged by taking the name Russian and founded the Kiyev princedom. As it is known, the Khazars were influential in the establishment of this princedom. This princedom, which encountered the Pecheneg, Uz and Kuman / Kipchak tribes after the Khazars and was constantly attacked by them, claimed that the Turkish tribes did not establish a state in history writing.. That is why we use this expression today in our own historiography when describing them.
\end{abstract}

Keywords: Pechenegs, Byzantium, Khazars, Slavs, Historiography, Russian Empire

\title{
EXTENDED ABSTRACT
}

During the two centuries of the Russian Empire lasting roughly between 1721 and 1917 , Russian historiography progressed to a great degree and produced many important studies. Scientists, especially those who study ancient Russian history, have found Turks, with whom they have lived neighbor relations for centuries, as the first nation while writing their works. Yet, they had a big trouble on writing this history as they didn't have enough knowledge and methodology about how they would manage this historiography. In order to overcome this challenge, during the era of Peter I, they invited foreign historians, particularly from Germany to the Petersburg Academy of Sciences beginning from 1725, with the aim of revising and rewriting Russian History. So, these scientists paved the way for redefining Russian history. We can mention G. Z. Bayer (1694-1738), G. F. Miller (1705-1783) ve A. L. Schletzer (17351809 ) as the most prominent German scholars in the course of first half of the $18^{\text {th }}$ century of Russian historiography. 
The writing of Russian history by foreign scientists instead of Russian historians was harshly criticized by V. N. Tatišev (1685-1750), one of the rare Russian historians for these dates and this criticism was also mentioned by other Russian historians later. In the end, this struggle of him came to an end with the transition to the understanding of local historians in the period of Catherine II (1762-1796) after his death. M. V. Lomonosov (1711-1765) was the first person who wrote about the history of the Russian people.

The most commonly used sources of Russian historians in writing the history of the Russians, are the general and local chronicles written in churches and monasteries during the reign of the Kiev Princedom and the Tsardom of Moscow. These chronicles were academically published with the name of "Polneye Sobraniye Russkih Letopis" with the most contribution made by Tatisev. In writing Russian history, the Russian historians called the struggle that they had with other nations on this geography as "the Struggle of Forest with Steppe". Russians were living in forests, on the other hand Turks were living in steppes. This viewpoint lasted during 200 years of Russian Empire and affected all the works written based on Russian chronicles, including information on Russian people and history. Furthermore, these historians accepted all Turkish tribes such as the Khazars, Pechenegs, Uzs, Cumans, Berendis and Qaraqalpaqs as one nation and so they presented the knowledge about them in this perspective. N.M. Karamzin, N.H. Ustriyalov, S.M. Solovyev, H.I. Kostomarov and D.I. Ilovayskiy can be counted among those who have written on the history of Russia in this period. Albert, one of the priests of the Trium Fontium Monastery, was the first to give information about these Turkish tribes in the works they wrote. Later, Kunik, Burackov, Aristov, Kostormarov et al followed him.

The basis of our study consists of two studies specifically written about the Pechenegs in the second half of the 19th century. First one is "Vizantiya i Pečenegi (Byzantium and the Pechenegs)" written by V. G. Vasilevsky and the latter is the study of P. G. Golubovsky published with the title "Uzs, Pechenegs and Cumans until Mongol Invasion".

Vasilyevskiy used all the sources written up to his time, especially Byzantine sources in his article.. He mentioned only about the political history of Pechenegs. While writing this history in detail, he tried to give message that Pechenegs were perceived quite incorrigible by the Byzantines.

He says that the Pechenegs filled the gap that emerged as a result of the collapse of the Bulgarian Tsarism. He said that they were no less terrible enemies for Byzantium in the 11 th and 13th centuries than their brothers in Asia, the Seljuk Turks. Therefore, he said that although the Byzantine sources that gave information about them were essentially true, they contained quite a lot of Byzantine rhetoric in them. For this reason, he emphasizes that more careful comments should be made about the lives of these nations and they should be evaluated better. 
Vasilyevsky was the first to link the reason of the First Crusade to the help request of Byzantium which was squeezed by the Seljuk in Anatolia and Pechenegs in Balkans. Later, he described in detail the struggle between the two Pecheneg leaders, Turak and Kegen, in the Danube region. Vasilevsky then mentioned extensively about how the Pechenegs and Uzs were used by the Byzantines as military power. Additionally, he stated that the Pechenegs were going along with the Bogomils (Paulicians) and that the Bogomils were quite much affected by Manichaeism. The work of Vasilevsky gives us historical information till 1094 but it is not possible to find any data about Lebunium Battle on which Pechenegs lost historically their existence.

The next work that we can focus on, belongs to Golubovsky. It was the first academic work that was prepared according to the scientific principles, based on the sources and all the researches on this subject. Golubovskiy explained the Pecheneg, Uz and Cuman-Kipchaks, who ruled in the steppes of South Russia until the Mongol invasion period, and their relations with the Russian princedom in the region and their decisive influence on Russian history. For this reason, Golubovskiy's work has the characteristics of a source work that includes important evaluations, written as a result of an extensive research on these Turkish tribes, whose details about their history can only be learned from sources written by the historians of the states they have relation.

According to Golubovskiy; Pechenegs, Uzs and Cumans were the last nations that moved from Asia to Europe in the Middle Ages. In fact, this process ended with the Mongols who were blowing like a hurricane in the 13th century. The mentioned Turkish tribes started to play an important political role with their emergence in the steppes of South Russia. They occupied the area from the Ural River to the Danube River and entered into a struggle with many states. They were able to draw attention to themselves, sometimes with their military campaigns, sometimes by mediating trade with eastern countries, sometimes with their military forces that were always ready to enter into the service of the country which paid them most, and their names were included in Russian, Polish, Hungarian, Byzantine and Arab chronicles. Their reputation has spread to Western Europe.

He begins his work by saying "In order to understand how and to what extent the neighbor of the nomads influenced the political life of ancient Russia, it is necessary to study how the relationship between Turks and Slavs was." First of all, he emphasized the characteristics of the South Russian geography and explained living conditions in these lands.

Golubovsky, then, focused on the origin of the Pecheneg word, the meaning of it and where it came from. He argued that Uzs, Cumans and Pechenegs came from the same ethnical race, but he tried to reveal that they were different tribes. And, he pointed out that; 
1. Pechenegs, Uzs, Cumans, Seljuk Turks, Ottoman Turks represented a single Turkish race.

2. All of these tribes were the branches of a nation that once lived the steppe life in Turkestan region.

As we mentioned above, Golubovsky explained the relations between the Pechenegs and the Russians, the Hungarians, the Byzantines in the geography extending from the Volga River to the Balkans by trying to use all the sources of his time. According to Golubovsky, the Turkish tribes were dangerous enemies of the Russians, but they also represented a force that was always ready to support the desired work for a certain fee.

Golubovsky agreed with Vasilyvsky's view that both the Pecheneg Turks and the Seljuk Turks were effective in the destruction of the Byzantine Empire. Contrary to Vasilyvsky, Golubovkiy gave information about the cultural lives of Turkish tribes. However, he complained about the lack of information on the culture of these Turkish tribes and gave the following information briefly: The Pechenegs, Uzs and Cumans were all Turk, all of them lived in the steppe, so their traditions and customs would have to be in common. They brought them from their homeland, Turkestan, and kept them without changing. He added that the culture of their new neighbors had an impact on them as well, but this effect was not deeply penetrated; only Turks settled in the cities, which were not too crowded, could have lost their fundamental traditions. And then, in particularly with an evaluation of knowledge presented by Byzantine Emperor, he continued, after the death of the chieftain, the uncle's children obtained political power; there was a council, named as "komenton" and composed of public; both in peacetime and in wartime, they adjudicated here all the important events; the power of the chieftain and their effects in these councils were quite insignificant.

As a result, in this study, we tried to make a comparison of two works written on Pechenegs, in the period when Panslavism was highly effective. The common aspect of both studies was that the Pechenegs, who prevent the Russians reaching the Black Sea, were not shown in a state organization. 


\section{Giriş}

1721-1917 tarihleri arasında yaklaşık iki yüzyıl hüküm süren Rusya İmparatorluğu döneminde Rus tarihçiliği büyük bir gelişme göstererek önemli çalışmalara imza atmıştır. Özellikle eski Rus tarihine ait çalışma yapan bilim insanları eserlerini yazarlarken karşılarında yüzyıllar boyunca komşuluk ilişkileri yaşadıkları ilk millet olarak Türkleri bulmuşlardır. Ancak bu yazım sırasında büyük bir sorunla karşılaşmışlardır ki o da başlangıçta nasıl yazacaklarına dair bir bilgi birikimine ve yöntemine sahip olamamaları olmuştur. Bunu fark ettiklerinde yani 1725 'ten itibaren Petersburg illimler Akademi'sine yabancı özellikle de Alman tarihçileri davet ederek onlardan Rus tarihçilerini yetiştirmelerini istemişler ve böylece Rus tarihinin yeniden ele alınmasının önünü açmışlardır. Bu Alman bilim insanları arasından özellikle G. Z.Bayer (1694 -1738), G.F.Miller (1705 -1783) ve A.L Şletzer (1735-1809)'i 18. yüzyılın ilk yarısında Rus tarihine damgasını vuranlar arasında ilk sırada sayabiliriz.'

Kendi tarihlerini kendilerinin değil de yabancıların yazması Rusya'nın o dönemlerde ender yetiştirdiği tarihçilerinden biri olan V.N.Tatişev (1685-1750) tarafından şiddetle eleştirilmiş ve onu daha sonra diğerleri izlemiştir. Sonunda onun bu mücadelesi ölümünden sonra II. Yekatarina (1762-1796) döneminde yerli tarihçi anlayışına geçilmesi ile büyük ölçüde son bulmuştur.

Rus milletinin tarihini ilk ele alan M. V. Lomonosov (1711-1765) olmuştur. Asıl mesleği kimyagerlik olan ve profesör unvanını alan Lomonosov daha sonra tarihi milletlerin hayatını özetleyip, geleceğe dair ona ümit verecek en önemli unsurlardan biri olarak gördüğü için bu mesleğe merak sarmıştır. Çalışmalarına önce yeni başladığı bu alanı tanımaya, bilgilenmeye ve kaynaklarına vakıf olmakla başlamış, daha sonra Rusların Norman menşeili oldukları tezini kabul etmeyerek, Rusların Slav asıllı olduklarını, Rus tarihinin Rurik'ten önce başladığını öne sürmüştür. Daha sonra da doğu ve güneydoğu Avrupa (Balkanlar) ile ilgili dönemindeki bütün kaynakları tarayarak, Slav kökenli yer isimleri üzerinde araştırmalar yapmış ve Alman tarihçilerin tezlerini çürütmüştür. ${ }^{2}$

M.V. Lomonosov'un fikirlerinin takipçisi ise Türk kökenden gelen N.M. Karamzin, olmuştur. Karamzin, Rusya Devleti'nin Tarihi adlı eserinde başlangıçtan 1612 yılına kadar olan dönemi ele almış ve kendi bakış açısına göre de Rus monarşisini övmüştür. Ayrıca eserinde oldukça fazla kaynak kullanması ve uslûba dikkat etmesi, eserin önemini ve kalitesini o dönemde yazılan diğer eserlerden olumlu olarak ayırmıştır. Daha sonra 18. yüzyılın ilk yarısından itibaren yabancı tarihçiler tarafından kurulan tarih okulu, yapılan araştırmalar ile güçlenmiş ve Bilimler Akademisi faaliyetleri neticesinde Rus tarih anlayışının temellerinin atılmasını sağlamıştır. Böylece 18. yüzyılın ilk yarısında başlayan tarih ile ilgili çalışmalarda, Bilimler

1 М. А. Алпатов, Русская историческая мысль и Западная Европа (XVIII-Первая Половина XIX.в), Москва 1985, s.15-34. (M.A. Alpatov, Russkaya İstoriçeskaya Mısl i Zapadnaya Yevropa (XVIII-Pervaya Polovina XIX v, Moskva 1985); Eserde bu üç tarihçinin hayatları ele alınmış ve Rus tarihine bakışları ve yaptıkları çalışmalar detaylı bir şekilde anlatılmıştır.

2 Алпатов, a.g.e., s.61-71. 
Akademisi hem Rusların kendi tarihlerini yazmalarında hem de diğer milletlerin tarihleri ile ilgili çalışmalar yapmaya başlamalarında önemli bir rol oynamıştır. Yukarıda da ifade ettiğimiz gibi kendi tarihlerinin başlangıcında karşılaştıkları ilk millet Türkler olduğu için her iki milletin tarihinin bu coğrafyada hem siyasi mücadeleler hem de kültürel etkilenmeler ile geçtiğinin ortaya konulması bu araştırmalar sayesinde olmuştur.

Çoğunluğunu Slavların oluşturduğu ve Rus adı ile ortaya çıkan bu birlikteliğin milletleşme ve siyasî bir birlik ortaya koymaları çok geç gerçekleşmiş, tarihler 852'yi gösterdiğinde Rurik'in önderliğinde Kiyev Knyazlığı kurulmuştur. Aslında Kiyev Knyazlığı'nın siyasî teşekkül olarak ortaya çıkmasında Bizans ile aralarında tampon bir devletin kurulmasını ekonomik ve siyasî çıkarları açısından önemli gören Hazar Kağanlığı sağlamış, bu yüzden de Knyazlığın içindeki Doğu Slavyan boylarından bazılarını kendisine 965 yılına kadar vergi ödemek zorunda bırakmıştır. Hazarlardan sonra karşılaştıkları ikinci Türk gücü Peçenekler olmuştur. Peçenekler 9. yüzyılın sonlarına doğru 890-96 arasında güney Rus topraklarına gelmişler ve 1036'ya kadar yaşadıkları bu coğrafyanın mutlak sahibi olarak; hem bu devletin istedikleri gibi güçlenmesini hem de Karadeniz'e inmesini engellemişlerdir.

Peçeneklerin arkasından da önce Uzlar daha sonra da Kuman/Kıpçaklar, bu Knyazlığın topraklarının sınırlarına gelerek en amansız düşmanları olmuşlardır. Öyle ki 20. yüzyıl tarih yazımında Kuman/Kıpçaklar ile yaşanan mücadelenin adı "Stepnaya Barba: Bozkırla Savaş" adı altında incelenip anlatılırken; Hazarlardan başlayarak Kuman/Kıpçaklara kadar olan siyasî mücadele de "Ormanın Bozkırla Mücadelesi” olarak anlatılmıştır.

Konumuzu teşkil eden Peçeneklerin siyasîtarihleri hakkında kısaca bilgi vermek gerekirse, Peçenekler ana yurtları olan Aral Denizi ile Sır Derya'nın orta akımları arasındaki topraklarda kadim merkezleri bugünkü Taşkent civarlarında yaşarlarken ${ }^{14}$ ticarette önemli bir yer edinmişlerdir. 744 yılında Köktürk Kağanlığının yıkılması üzerine bu topraklarda iktidar el değiştirerek, Uygur, Oğuz ve Karluklara geçmiş, Oğuzların Aral Gölü ile Aşağı Sır Derya bozkırlarına yerleşmeleri zamanla zorunlu olarak Peçeneklerin bu bölgeden uzaklaşmalarına sebep olmuştur. Olnarın bir kısmı Ouğzların yanında kalırken, bir kısmı da Hazar Denizinin kuzeyinden Karadeniz'in kuzey düzlüklerine gelmişlerdir. Geldiklerinde tarihler bu sırada 89096'lı yılları gösteriyordu. Ancak bu geliş kuzeyden güneye inerek hâkimieyt kurmaya çalışan Kiyev Knyazlığını rahatsız etmiş ise de knyazlık başlangıçta onları tanımaya çalışmanın kendileri için daha iyi olacağına karar vermiştir. Peçenekler ise bu orman kavimleri ile mücadele etmenin kendilerini çok zorlamayacağını fark etmişlerdir. Aslında Slavlar için Peçenekler şimdilik korkulacak bir düşman olarak durmuyorlardı ama Hazar korkusu başlarında iken yeni bir korkuya ihtiyaçları olmadığını düşünerek mutedil bir siyaset izlemeye karar vermişlerdir. Bundan sonra Peçenekler kuzey Karadeniz bölgesinde gittikçe güçlenirken, Kiyev Knyazlığı de bütün Doğu Slavyan boyları ile Fin-Ugr boylarını tek çatı altında birleştirerek güçlü bir devlete dönüşme hazırlıklarına başlamıştır. 
Başlangıçta hem Kiyev Knyazlığı hem de Peçenekler açısından her şey iyi gelişmiştir. Ancak Bulgar hükümdarı Çar II. Simeon'un bitip tükenmez bilmeyen istekleri Bizans'ı hem Ruslardan hem de Peçeneklerden yardım istemek zorunda bırakmıştır. Bu vesile ile 915 yıında Peçenekler ilk defa Kiyev Knyazlığı topraklarının içinden geçmişlerdir. Bundan sonraki ikinci yakınlaşma 944-45 yılında Knyaz Oleg'in İstanbul kuşatmasına Peçenekleri ücretli asker $^{3}$ olarak aldığında gerçekleşmiştir. Knyaz Svyatoslav zamanına kadar gayet dostâne seyreden ilişkiler, bu knyazın zamanında tam tersine dönmüştür. 968'de Kiyev'i kuşatmaları ve 972'de de kendisini tam bir Peçenek başbuğu gibi yetiştiren bu knyazın onlar tarafından ortadan kaldırılması aralarının bir daha düzelmemek üzere bozulmasına sebep olmuştur. Bu tarihten sonra Peçenekler üstün bir şekilde Kiyev Knyazlığına bağlı topraklarda istedikleri gibi at koşturmuşlardır. Bu durum 1036 yılına kadar devam etmiştir. Bu sırada Kiyev'de iç mücadeleler yaşanmış ve sonunda Yaroslav (1019-1054) knyazlık tahtına çıkmıştır. Yaptığı ilk iş topraklarına sürekli akınlar düzenleyerek halkını zor durumda bırakan Peçeneklere gereken cevabı vermek olmuştur. Çok geçmeden istediğine ulaşmış ve yapılan savaşta onları öyle bir yenmiştir ki büyük bir kısmı öldürülmüş, kalanlarda bu toprakları terk ederek Tuna'ya Balkanlara doğru hareket etmişlerdir. Bu arada bu topraklarda yerleşip kök salanlar knyazlık tarafından sınır boylarına yerleştirilmişler ve zaman zamanda ücretli asker olarak kendilerinden istifade edilmiştir.

Tuna'ya doğru gidenlerin göçü yaklaşık on iki yıl sürmüş, 1048'larda Tuna boylarına geldiklerinde bu sefer de Bizans'ın en amansız düşmanı olmaya hazırlanmışlardır ki bu düşmanlık 1091 yılına kadar sürmüştür. Bizans kaynakları yaklaşık 53 yıl süren bu mücadeleyi teferruatlı bir şekilde anlatmışlardır. Peçeneklere son darbeyi 29 Nisan 1091'de Bizans imparatoru Aleksios Komnenos vurmuş ve o gün yapılan Lebunium Meydan savaşında onların siyasî yapılarını tarih sahnesinden kaldırmıştır. ${ }^{4}$

\section{Bulgular}

Çok kısa bir şekilde tarihlerini verdiğimiz Peçeneklerin Rus topraklarında 145 yıl süren tarihlerinin tarih yazımındaki varlığı da güçlü olmuştur. Rus tarihçilerinin, Rusların tarihini yazarken en fazla kullandıkları eserler, Kiyev Knyazlığı ve Moskova Çarlığı döneminde kilise ve manastırlarda yazılan genel ve yerel yıllıklardır. Bu yıllıklar 18. yüzyılda Polneye Sobraniye Russkih Letopis adı altında yayınlanarak bilim dünyasına kazandırılmışlardır ki bu konuda en fazla çalışmayı da V.N. Tatişev yapmıştır. Rus tarihçiler, Rusya tarihini yazarlarken bu coğrafyada karşılaştıkları milletlerle olan mücadelelerini yukarıda da ifade ettiğimiz üzere “Ormanın Bozkırla Mücadelesi” olarak değerlendirmişlerdir. Ruslar ormanlı bir kavim; Türkler ise bozkırlı bir millettir. Bu bakış açısı imparatorluk döneminde yazılan bütün eserlerde etkili olmuştur. Burada yaklaşık 300 yıl süren bu dönemde Rus ve Rusya tarihi çalışmaları içerisin-

3 Yıllık yazarları Peçeneklerin yardıma gitmelerini onların ücretli olarak kiralandıkları şeklinde yorumlayarak kaydetmişlerdir.

4 Geniş bilgi için bkz: M. Uydu Yücel, Türkistan'dan Tuna'ya Peçenekler, Doğu Kütüphanesi Yayınları, İstanbul 2020. 
de Rus yıllıklarının verdikleri bilgiler çerçevesinde değerlendirildiklerini söyleyebiliriz. Ayrıca Hazar-Peçenek-Uz-Kuman/Kıpçak, Berendiler, Karakalpaklılar ile olan ilişkileri birbirinden ayırmadan hepsini bir millet olarak gördüklerinden birlikte vermişlerdir. Bu dönemde Rusya Tarihi üzerine eser verenler arasında N.M. Karamzin ${ }^{5}$, N.H. Ustriyalov, ${ }^{6}$ S.M. Solovyev ${ }^{7}$, H.I. $K$ ostomarov $^{8}$ ve D.i. İlovayskiy'i` sayabiliriz. Bu Türk boyları hakkında yazdıkları eserlerde bilgi verenler arasında ilk çalışmayı yapan ise Trium Fontium Manastırı rahiplerinden Albert olmuştur ${ }^{10}$. Onu daha sonra A.O. Kunik ${ }^{11}$, P.O. Buraçkov ${ }^{12}$, N.A. Aristov, ${ }^{13}$, N.I. Kostormarov vd izlemişlerdir.

Bizim bu çalışmamızın esasını 19. yüzyılın ikinci yarısında Peçenekler hakkında özel olarak kaleme alınan iki araştırma oluşturmaktadır. Birincisi V.G. Vasilyevskiy'in yazığı “Vizantiya i Peçenegi: Bizans ve Peçenekler"14 ismini taşıyan çalışma ile P.G. Golubovksiy'in kaleme aldığı "Moğol İstilasına Kadar Uzlar, Peçenekler ve Kuman/Kıpçaklar" adlı eserdir. ${ }^{15}$

Vasilyevskiy makalesinde, kendi zamanına kadar yazılan bütün kaynakları özellikle de Bizans kaynaklarını kullanmıştır. Peçeneklerin Balkanlara gelişi, Bizans için 1091 yılına kadar

5 Н. М., Карамзин, История государства Российского, Т. 1-2. СПб., 1818-1826 (N. М. Karamzin, İstoriya gosudorstva Rossiyskogo, C. 1-2. Sank-Peterburg, 1818-1826.).

6 Н. Г., Устрялов. Русская история, в 2 ч., СПб., 1855 (N.G. Ustryalov, Russkaya Istoriya, в 2 ч., SankPeterburg, 1855.).

7 С.М. Соловьев, Истории России с древнейших времён, С.I, Москва, 1851 S.M. Solovyev, İstoriya Rossii s Drevneyşı Vremyon, C.I, Moskva 1851).

8 Н. И. Костомаров, История России в жизнеописаниях ее главнейших деятелей, Т. 1-3. - Санкт-Петербург, 1915. (N.I. Kostomarov, İstoriya Rossi v Jizneopisaniyah yiyo Glavşeynıh Deyateley, C.1., Sank-Peterburg).

9 Д. И. Иловайский, История России, в 5 т.: в 7 кн. - М., 1876-1905. - Том 1. Часть 1: Киевский период, VIII, 333 c. (D. İ. Illovayskiy, İstoriya Rossii), v t c.: v 7kn. M., 1876-1905, C.1 Çast 1, Kiyevskiy Period VIII, 333c).

10 Ulrih Fridrih Sum, İstoriç. Rassujdenie o Patsinakah ili Peçenegah, Çiteniya v İst. Obş. İst. Drevn. Ross., 1846, No:1, s.22-24, C.10). Bu eserde özellikle, Peçenekler tarafından kovulan Macarları Arnulf'un 883'de çağırdığı bilgisine yer verilmiştir.

11 А.Куник, О торкских печенегах и половцах по венгерским источникам // Зап. Академии наук. СПб., 1854. Отд. I, III s.734. (A.O. Kunik, O Torkskih Peçenegah i Polovtsah po Vengerskih İstoçnikam, Zap Akademii Nauk Sank-Peterburg, 1854, Otd. I, III, s.734). Bu eserde Türk boylarının Macaristan'daki siyasi ve kültürel durumları ile bu coğrafyadaki yerleşimleri hakkında bilgi verilmektedir.

12 П.О. Бурачков, Опыт исследования о куманах, или половцах // Зап. ООИД., 1877, Т.Х, s.111-138 (Р.0. Buraçkov, Opıt isledovaniya o Kumanah ili Polovtsah, Zap 00iD, 1877, C.X, s.111-138).

13 Н. А Аристов, О земле Половечкой. Исгорию-гшграфическй очеркь // Извеспя исгоримэ-филологичесшго факультета Института кн. Безборода вь Нежине за 1877 г. -Юевь, 1877 (N.A. Aristov, O Zemle Polovetskoy, İstoriyu-gigrafiçeskiy Oçerk, İzvestiya isgorime-filologiçesşego fakülteta Şmstitura kn. Bezboroda v Nejime za 1877 g. Kiyev 1877; Н.А. Аристов, Заметки об этническом составе тюркских народов // Живая старина. Т. 6. Вып. 3-4. 1896 (N. A. Aristov, "Zametki ob Etniçeskoy sostave Turskih Narodov", Jivaya Starina, T. 6. Вып. 3-4. 1896).

14 Н.И.Костомаров, Чертынародной южснорусской истории// Историческиемонографиииисследования. Т. 1.СПб, 1903 (N.i. Kostormarov, Çertı Narodnoy Yujnorusskoy Istorii, İstoriçeskiye monografii i İsledovaniya, C. 1. Sank-Peterburg 1903).

15 В.Г. Васильевский, Византия и печенега // настояшем издании: T. 1, c.8-189. (V.G. Vasilyevskiy, Vizantiya i Peçenega", Nastoyaşem İzdanii, T.1, c.8-189). Biz bu çalışmamızda В.Г Васильевский, "Византия и печенега " Труды. -СПб., 2010 (Vizantiya i Peçenega”, Trud, Sank-Peterburg 2010) baskısını kullandık. Vasilyevskiy'in bu çalışmasının önemli kısımları ve görüşleri "Rus Tarihçi Vasili Gregorieviç Vasilevskiy'in Kaleminden BizansPeçenek Münasebetleri”, Bozkırın Oğlu Ahmet Taşağıl Armağanı, Yeditepe Yay., İstanbul 2019, s.265-296'de tarafımızdan aktarıımıştır. 
sürecek olan bir süreci de beraberinde getirmiştir. Bu tarihi en ince detaylarına kadar anlatarak, Peçeneklerin Bizans tarafından iflah olmaz bir millet olarak görüldüklerini satır aralarında belirtmeye çalışmıştır. Başlangıçta Bulgar-Bizans ilişkileri üzerinden Peçeneklere bir giriş yapmakta ve o dönemde yani 10. yüzyılının ilk yıllarında Bizans imparatoru olan Konstantinos Porhyregennetos'un oğluna ithafen yazdığı eserinden bahsederek “Bizans'ın kuzeyindeki denge sisteminin Peçenekler tarafından bozulduğunu ve onların izni olmadan Bulgarların İstanbul önlerine kadar gelemeyeceğini o yüzden de Bizans imparatorunun Bulgarları korkutmak istediği zaman Peçeneklerden istifade ettiğini" ifade etmiştir. ${ }^{16}$

Vasilyevskiy, I. Bulgar Kağanlığının (Tuna Bulgar Kağanlığı) yıkılması sonucu ortaya çıkan boşluğu Peçeneklerin doldurduğunu, onların 11-13. yüzyıl Bizans yönetimi için, Asya'daki kardeşleri olan Selçuklu Türklerinden daha az korkunç düşmanlar olmadıklarını ve bu yüzden de onlar hakkında bilgi veren Bizans kaynaklarının özünde doğru olmakla birlikte, içlerinde oldukça fazla Bizans hitabet sanatını barındırdıklarını söylemekte ve bu nedenle, bu milletlerin yaşayışları hakkında daha dikkatli yorumların yapılarak daha iyi değerlendirilmeleri gerektiği üzerinde durmaktadır. 0 devamında, "11. yüzyılın ortalarına doğru Peçenekler Tuna nehrini aştılar. Yeni tarih yazılarının tümünde üzerinde fazla durulmamış bu olay, insanlık tarihi açısından büyük öneme sahiptir. Sonuçları açısından neredeyse, Kavimler Göçünü başlatmış olan, Batı Gotlarının Tuna nehrini aşması kadar önemlidir. Özellikle Rus ve Bizans tarihlerinde yanlış yerleştirilen ve büyük hata olan şudur ki; çeşitli Türk boyları arasındaki akrabalık bağları göz ardı edilerek, sanki birbirlerinden farklılarmış gibi, bazılarını Tork, bazılarını ise Türk diye isimlendirmiş olmalarıdır. Örneğin, Peçenekler ve Uzlar ya da Kuman/Kıpçaklar, aynen Selçuklu Türkleri gibi Türklerdir" diyerek Peçeneklerin Tuna boylarını aşmalarını Kavimler Göçü kadar etkili bulmaktadır. ${ }^{17}$

Ona göre “Eğer Peçenekler ile Selçuklu Türklerinin aynı soydan oldukları hususu gözden kaçırılmamış olsaydı, şüphesiz tarihte, Peçeneklerin Tuna nehrini aşıp Bizans imparatorluğunun alanına girmeleri ve Selçukluların Anadolu'daki başarıları arasındaki bağlantı çabucak fark edilebilecekti. 11. yüzyılın sonuna doğru, Avrupa ve Anadolu'daki istilaların, birbirlerine el vermek için uğraştığını göreceğiz. Batıdan doğuya olan büyük seferin, yani Birinci Haçlı Seferinin doğrudan nedeni, her ne kadar bu neden Doğu Imparatorluğu olarak ifade edilmiş olsa da Anadolu'daki Selçuklu fetihlerinden ziyade, İstanbul'u bile tehdit eder hale gelmiş, tehditkâr ve korkunç Peçenek milleti idi". Bu sözler Birinci Haçlı Seferinin sebebini Anadolu'da Bizans'ı sıkıştıran Selçuklu Türkleri ile Balkanlarda zor durumda bırakan Peçenek Türkleri

16 П.В. Голубовскш, Печенега, горки и половцы до нашествш татар. История южнорусских степей 1 Х-ХШ въ., Клевь, 1884 (P.G. Golubovskiy, Peçenega, Turki i Polovtsı do Naşestvi Tatar, İstoriya Yujnorusskih Stepey IX-XIII Vv, Kiyev 1884). Biz çalışmamızda bu eserin 2011 baskısını kullandık ayrıca bu eser tarafımızdan yaptırılan bir tez ile de Türkçe'ye kazandırılmıştır. Bkz: N. Kumru, P.V. Golubovskiy ve Eseri: Peçenegi, Torki i Polovtsi do Naşestviya Tatar: Moğol İstilasına Kadar Peçenekleri Uzlar ve Kuman/Kıpçaklar, XI-XIII. yüzyıllardaki Güney Rusya Bozkırlarının Tarihi, İ.Ü. Sosyal Bilimler Enstitüsü Yayınlanmamış Yüksek Lisans Tezi, İstanbul 2016. 
olarak gördüğünü ifade etmektedir. Yani Vasilyevskiy ilk defa Birinci Haçlı Seferinin sebebini Türkler tarafından sıkıştıılan Bizans'ın yardım istemesine bağlamaktadır ki bu tarih yazımında ilk defa dile getirilmiştir. ${ }^{18}$

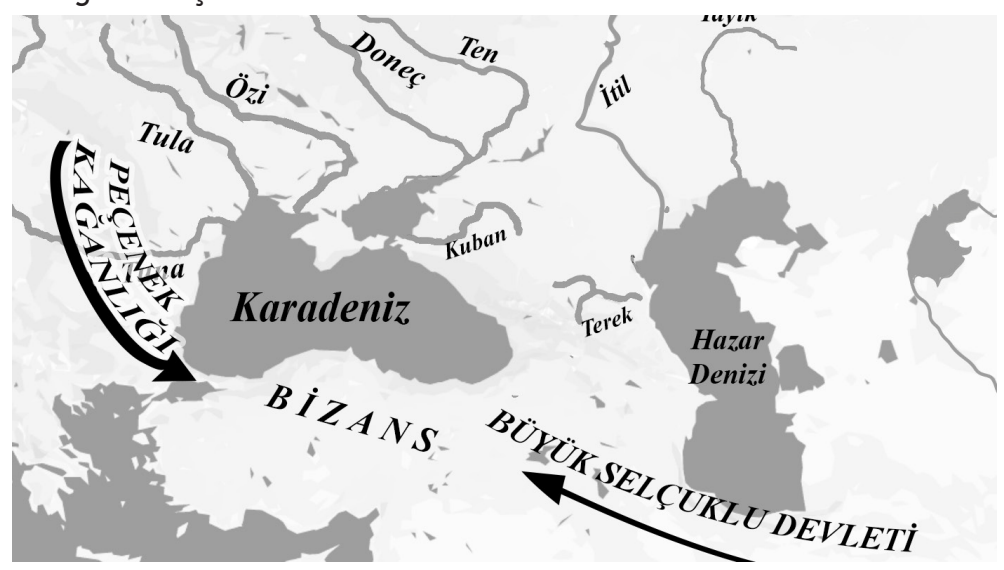

Vasilyevskiy bundan sonra Tuna boylarında Turak ile Kegen adlarındaki iki Peçenek başbuğu arasındaki mücadeleyi en ince detaylarına kadar anlatmaktadır. Bunu anlatırken zaman içerisinde her iki başbuğun Hristiyan olmasını kendisi de bir Hristiyan olarak o çerçevede yazmış ve Kegen'in Hristiyan olmasını şöyle yorumlamıştır: “Bir Hristiyan olarak vaftiz edilmek, din değiştirmeye farklı bir örnek teşkil eden bu barbarın sert yüreğini herhangi bir şekilde yumuşatmamıştı. Düşmanına karşı gütmekte olduğu kan davası Kegen'in asıl amacını teşkil etmeye devam etmiştir". ${ }^{19}$

Vasilyevskiy, Bizans'ın doğudan Selçuklu Devleti tarafından sıkıştırılması üzerine Peçeneklere başvurduğunu, onlarla mücadele etmek üzere 15.000 Peçenek atlısını çeşitli ve değerli hediyeler vererek yola çıkardığını ancak onların yolda gitmekten vazgeçtiklerini eğer vazgeçmemiş olsalardı “İstanbul'a bakan, Bitinya'da ${ }^{20}$ bir Peçenek Kağanlığının kurulmasının kaçınılmaz olacağını ifade etmiştir. ${ }^{21}$

Vasilyevskiy daha sonra Peçeneklerin ve Uzların askerî yönden Bizans tarafından nasıl kullanıldıklarına geniş bir şekilde değinmiştir. Kısaca o; “Konargöçer bir hayat tarzı yaşamaları Bizans'ın elde ettiği esirleri yerleştirmelerine ve yerleşik hayata geçmelerine sebep olmuşsa da bir zamanlar II. Basileios tarafından kılıçla çizilen hükümdarlık sınırları içine yerleştirilmiş olan Uzlar ve Peçenekler, IV. Romanos'un Türkler üzerine düzenlediği seferlerde aktif rol oynamışlardır. Yine onlar, Bizans ordusunun, boylarla yapılan savaşlarda son derece önem arz eden ve aynı zamanda konargöçer akıncılarının cesaret ve süratini muhafaza eden hafif süvari bölümünü teşkil etmişlerdir. Öncü birlikler ve gözcü birlikler olarak Uzlar ve Peçenekler

18 Vasilyevskiy, a.g.m., s.13.

19 M.Uydu Yücel, "Rusya İmparatorluğu Tarih Yazımında Haçlı Seferleri”, I.Ü. Tarih Dergisi, S. 66, 2017/2, s. 15-34.

20 Uydu Yücel, Türkistan'dan Tuna'ya Peçenekler, s. 326.

21 Vasilyevskiy, a.g.m., s. 13-14. 
kullanılmışlardır. Yorgun Bizans kuvvetleri, güçlerini ne ile yerine getireceklerini bilmeden mola verdikleri vakit, atlarından bile inmemiş olan Peçenekler, hemen erzak temini için bölgeye atılmışlardır. Düşmanın eline geçmiş olan toprakları tahrip etmek gerektiğinde de yine Uzlar öne sürülmüşlerdir. Kısacası, eski bozkır atlılarının hizmetleri Bizans kuvvetlerine son derece fayda sağlamıştır. Ancak bu tür birlikleri kullanmanın bir tehlikesi ve sakıncası vardı o da birbirine benzer dili konuşan bu Türklerin savaşlar sırasında birbirlerini tanımaları ve birbirlerine karşı savaşmamaları idi" .22 Nitekim Vasilyevskiy, Malazgirt savaşında yaşananları "Millet ve boyların yakınlaşmalarında hiç de azımsanmayan katkısı konusunda tarihin hakkını teslim ettiği Bizans devleti, Türk boylarının ayrılmış iki kolunu da böylece birbiri ile tanıştırmış oldu. Bu tanışma gelecek olayların gidişatında gayet etkili olmuş ve imparatorluğa da oldukça büyük zarar vermiştir" demektedir. İlave olarak; "Uz-Peçeneklerin kendileri, en üst düzeyde hareketli, nüfusun en huzursuz, yerinde duramayan öğesi olarak görünüyorlardı. Her an atlarıan atlayıp, kendilerine ödül ve yağma sözü veren herhangi bir maceracının peşine takılıp gitmeye hazırlardı. Öyle ki, Bizans yönetiminden memnun olmayan, intikam almayı düşünen, Justinianos ve Basileios'un tahtında oturmak için hak iddia eden herhangi birinin, hazır ve istekli tam bir yardımcı ordu bulması için sadece Balkanları aşması yeterliydi” demektedir. ${ }^{23}$

Vasilyevskiy Peçenekler ile en fazla mücadele denen Bizans İmparatorunun Aleksios Komnnenos olduğunu ifade ettikten sonra; "Başarının cesaretlendirdiği Imparator Aleksios, bu istenmeyen misafirleri uyarmak için, Balkanların ardına geçmeye, mümkünse de Peçenekleri imparatorluk mülkünden yani imparatorluğun sınırları sayılan Tuna'dan öteye atmaya karar verdi" diyerek Aleksios Komnnenos'un 1081'den 1091'e kadar giden süreçte karşılaştığı en büyük zorluğun Peçenekler olduğunu ve verdiği büyük mücadele sonucunda zaferi göğüslediğini ifade etmektedir. ${ }^{24}$

Vasilyevskiy, Bizans'a karşı olumlu bir görüş bildirmemekte, Batı ve Hristiyanlığın insanların ve toplumların hayatlarına bir fiil nüfûz ettiklerini söyleyerek eleştirmekte, devamında özellikle bir düşman yarattıklarını, Hristiyan mabedini kirletenleri ve dindar hacıları yollarından alıkoyanları o dönemde Uz ve Peçenekler olarak gösterildiklerini söyleyerek bu durumu alaycı bir dille anlatmaktadır. Vasilyevskiy çalışmasını 1094 yıına kadar getirmekte ancak Peçenek kağanlığını tarih sahnesinden silen Lebunium Meydan Savaşı (29 Nisan 1091) hakkında bir bilgi vermemektedir.

Özetle bu çalışmayı değerlendirdiğimizde Vasilyevskiy'in neden Peçeneklerin siyasî hayatlarının tamamını ele almak yerine sadece Bizans ile olan mücadelesini ele almayı tercih etmiştir sorusu ilk aklımıza gelen soru olmuştur. Cevabın şıkları arasında onun Bizans tarihinde uzman birisi olması elbette ki önemlidir ama bunu açıklamaya kanaatimizce yetmemektedir. Rusları Karadeniz sularına indirmeyen Peçenekler yerine Bizans'ı Balkanlarda perişan eden

22 Bugünkü Kocaeli, Sakarya, Bolu, Bursa illerini içine alan bölge

23 Vasilyevskiy, a.g.m., s.17.

24 Vasilyevskiy, a.g.m., s.37. 
Peçeneklerden yana tavrını koyması da önemlidir. Eserin yazıldığı dönem Panslavizm akımının ve düşüncesinin tarih yazımında en yoğun yaşandığı dönemdir o yüzden Vasilyevskiy tercihini kendi tarihinde derin yaralar açan bir milleti kaleme almaktansa Bizans'ın o dönem en amansız düşmanı olan bu milleti yazmaktan yana kullanmıştır ki genel itibarı ile diğer eserlerine baktığımızda bunu rahatça görebiliriz. Yine çalışmanın tamamına bakıldığında dar Hristiyanlık taassubu içerisinde sıkışan Bizans karşısında bozkır yaşamının sağladığı rahatlık ve imkânlar ile savaşan Peçeneklere devlet oluşumu içerisinde yer vermemekle beraber satır aralarında başbuğlarının, halkının, meclisinin, ordusunun, töre-yasalarının, bayraklarının olduğunu ve diğer devletler ile anlaşmalar yaptıklarını söylemektedir. Devlet veya kağanlık olarak adlandırdığımız siyasî bir teşkilatlanmanın olmazsa olmazları yukarıda saydıklarımız değil midir? 0 zaman neden Peçenek boyu bir siyasî teşkilat kurmasın ki? 13 uruğ olarak Karadeniz ve Tuna sahillerinde yaşıyorlardı bunlar iç içlerinde serbest ama dış işlerinde bir araya gelip içlerinde en güçlü boyun başbuğu kim ise onun idaresi altında hareket ediyorlardı. Bu sistemi daha sonraki yıllarda uygulanan sancak veya eyalet sistemine benzetebiliriz. 0 yüzden kanaatimizce hem Peçenekler hem de Kuman/Kıpçaklar siyasî bir teşkilatlanma içerisinde olmuşlar ve kağanlıklarını kurmuşlardır.

Bir diğer çalışma ise P.V. Golubovskiy'e aittir. Eser, yazıldığı dönemde, bu konudaki kaynaklara ve yapılmış bütün araştırmalara dayanan, bilimsel esaslara göre hazırlanmış ilk bilimsel eser olma özelliğini taşımaktadır. Golubovskiy, Moğol istilası dönemine kadar Güney Rusya bozkırlarında hüküm süren Peçenek, Uz ve Kuman/Kıpçaklar ile bunların bölgedeki Rus knyazlıkları ile ilişkileri ve Rus tarihi üzerindeki belirleyici etkilerini anlatmıştır. Bu nedenle Golubovskiy'in eseri, tarihleri hakkındaki detayları ancak ilişkide bulunmuş oldukları devletlerin tarihçileri tarafından kaleme alınmış kaynaklardan öğrenebildiğimiz bu Türk boyları üzerine geniş bir araştırma sonucu yazılmış, önemli değerlendirmeler içeren kaynak eser özelliğini taşımaktadır.

O eserine “Konargöçerlerin komşuluğunun eski Rusya'nın siyaîi hayatını nasıl ve ne ölçüde etkilemiş olduğunun, Türkler ile Slavlar arasındaki ilişkinin nasıl olduğunun araştırılması ile ortaya çıkacağı kanaatinde" olduğunu söyleyerek başlamıştır ${ }^{25}$. Önce Güney Rus coğrafyasının nasıl bir özelliğe sahip olduğundan bahsederek, bu toprakların yaşama imkânları üzerinde durmuştur. Ona göre orman, yerleşik halklar için koruyucu bir özellik taşırken, konargöçerler açısından yıkıcı saldırılarda bulunmalarını engellemiştir. Açık alanlarda, savaş sanatları korkutucu olan Peçenek ve Kuman/Kıpçakların hafif süvari savaşçıları, ormana geldiklerinde yaya birlikler önünde teslim olmuşlardır. Tarımla uğraşan, toprağına ve geleneklerine sıkı sıkıya bağlı olan Slav halkı, eski yaşadıkları yerleri kolayca ve istekle terk etmemişlerdir. Ağır ağır, yüzyıllar içerisinde terk etmişler ve onların bu zor ve yavaş geri çekilmelerindeki en büyük yardımcıları ve koruyucuları ise orman olmuştur ${ }^{26}$ tespitinde bulunurken aslında kendisi ile de

25 Vasilyevskiy, a.g.m., s.45-48.

26 Vasilyevskiy, a.g.m., s.58. 
çelişkiye düşmektedir. Şöyle ki orman hem Slavları korumuş hem de Türk boylarını durdurmuştur. Öyle ise neden yavaş yavaş daha güneye inmişlerdir ki? Rus tarihçilerinin hepsinin ittifak ile söyledikleri ormanın yaşama hakkını kendilerine istedikleri gibi vermediğidir. 0 zaman rahat bir hayat sürmeyi engelleyen ormanda yüzyıllar içerisinde yaşamanın anlamı nedir? Sizi o coğrafyaya hapseden başka bir güç yoksa oradan hemen uzaklaşırsınız. Aslında onlar aşağıya doğru inerlerken önce Hazar daha sonra Peçenek, Uz ve Kuman/Kıpçakların setleri karşılaştılar ve o yüzden de aşağıya güçleri nispetinde yavaş yavaş inmek zorunda kaldılar. Ancak ne yazık ki kanaatimizce Golubovskiy'in döneminde bunu yazması mümkün olmamıştır.

Golubovskiy'e göre: “Orta çağ’da, Asya'dan Avrupa'ya doğru harekete geçen milletlerin en sonuncuları Peçenekler, Uzlar ve Kuman/Kıpçaklardır. Aslına bakılırsa bu süreç, 13. yüzyılda kasırga gibi esmiş olan Moğollarla sona ermiştir. Bahsedilen boylar, Güney Rusya bozkırlarında belirmeleriyle beraber önemli bir siyasî rol oynamaya da başlamışlardır. Yayık nehrinden Tuna nehrine kadar olan alanı işgal ederek, birçok devlet ile mücadeleye girmişlerdir. Bazen yapmış oldukları seferlerle, bazen doğu ülkeleri ile yapılan ticarete aracılık etmek suretiyle, bazen de kim daha fazla verirse onun hizmetine girmeye her zaman hazır olan askerî kuvvetleri ile dikkatleri kendi üzerlerine çekmeyi bilmişler ve isimleri Rus, Leh, Macar, Bizans ve Arap kroniklerinde yer almış, ünleri Batı Avrupa‘ya kadar yayılmıştır". ${ }^{27}$

Golubovskiy daha sonra Peçenek isminin kökeni ve nereden geldiği ile anlamı üzerinde durarak. Uz, Kuman/Kıpçak ve Peçeneklerin aynı ırktan geldiklerini ancak farklı boylar olduklarını ortaya koymaya çalışarak şu tespitlerde bulunmuştur:

1) Peçenekler, Uzlar, Kuman/Kıpçaklar, Selçuklu Türkleri, Osmanlı Türkleri tek bir Türk soyunu temsil etmektedir.

2) Bahsedilen boyların hepsi, bir zamanlar Türkistan bölgesinde bozkır hayatı sürmüş bir milletin kollarıdır ${ }^{28}$.

Yukarıda ifade ettiğimiz üzere Golubovskiy'de döneminin bütün kaynaklarını kullanmaya çalışarak, Peçeneklerin İtil'den Balkanlara kadar olan coğrafyada Ruslar, Macarlar ve Bizans ile olan ilişkilerini anlatmıştır. Ona göre Peçenekler Macarları güney Rus bozkırlarından çıkarmaya zorlamışlardır. Bu arada bütün 9.yüzyıl boyunca ve 10. yüzyılın 60 yıllarında yani 968 yılına kadar, Peçeneklerin Rus topraklarını hiç rahatsız etmemelerinin sebebini de şöyle açıklamaktadır: "Peçeneklerin nihai olarak Macarların hesabını görebilmeleri için zamana ihtiyaçları olduğu gerçeği yanında, Aziz Vladimir ve Yaropolk döneminde konargöçerlerin Rusların ilişkilerine karışmalarına ve zayıflıklarını görmelerine imkân veren iç kuvvet kavgaları henüz başlamamış olup, Rus topraklarında sükûnetin hüküm sürmesidir" demektedir. Peçenek-Rus münasebetlerini yıllıklardaki bilgiler üzerinden teferruatlı bir şekilde aktarırken

27 Golubovskiy, a.g.e., s.4.

28 Golubovskiy, a.g.e., s.16. 
onların 972'den itibaren güçlenerek Rusya'nın iç işlerinde bir fiil etkili olduklarını ve mücadelenin aralıksız ve çetin olarak 1036'ya kadar devam ettiğini, ancak sonunda kazanan tarafın Ruslar olduğunu belirtmektedir. ${ }^{29}$

Golubovskiy, Tuna boylarında görünen Peçeneklerin iki başbuğu arasında yaşanan mücadeleyi çok fazla yorum yapmadan anlatmakta sadece "Dedelerimiz şimdi artık daha tehlikeli ve güçlü bir düşmanla baş etmek zorundaydılar. Eğer Rusya, Peçenek ve Uzların komşuluğundan nispeten daha az zarar görmüş ise, bunu sadece şartların olumlu olmasına dayandırmak zorundayız. Görmüş olduğumuz üzere, 10. yüzyılın sonu, 11. yüzyılın başlarında Peçeneklerle mücadele büyük yoğunluğa ulaşmış, knyazlar takviye edilmiş şehirlerden oluşan bir hat kurmak durumunda kalmışlardı"30 demektedir.

Golubovskiy, Vasilyevskiy'in hem Peçenek Türklerinin hem de Selçuklu Türklerinin Bizans'ın yıkılmasında etkili olduğu görüşüne ise şu cümleler ile katılmaktadır: “Macaristan'da bozkırlıların akınlarına maruz kalmıştır, ancak bu Türkistanlı atıların azgın dalgalarından oraya sadece zayıflamış çırpıntılar ulaşmıştır. Nitekim Bizans da bunlardan az çekmemiştir. Umutsuzca, kuzeyde Peçenek ve Kuman/Kıpçaklara karşı, güneyde ise Selçuklu ve Osmanlı Türklerine karşı kendisini korumak durumunda kalmıştır. Eski zamanlarda birbirlerinden ayrılmış bulunan bu Türk kardeşler, uzun ayrılığın ardından yeniden birleşmek için, âdeta Bizans'ın bölgesinde birbirlerine ellerini uzatmışlardır. Belki de kuzeyliler, yani Peçenek ve Kuman/Kıpçaklar nihai olarak sarsmamış olsalardı, genç kardeşler olan Selçuklu ve Osmanlılar bu köhne, içine kapalı, dışında ise iflah olmaz kokuşmuş yaraları olan imparatorluğu yıkamazlardı. Gerçi Bizans Imparatorluğu kendi haline bırakılmış olsaydı bile varlığını uzun süre devam ettiremezdi, ancak Türkler bu ümitsiz hastanın ölümünü hızlandırmışlardır. Bizans, Türkistanlı kardeşlerin darbeleri ile yere yığılmıştır. Böylece Avrupa'ya doğru olan yol güneyden de açılmıştır. Bu yönden gelenlere karşı Avrupa'nın kalesi Macaristan olmuştur. Batı Avrupa devletlerinin kendilerinin Türklere karşı başarı ile karşı koyacak kadar güçlenmeleri çok daha sonra olmuştur. Doğudan gelen yol ise Rusya tarafından korunmuştur. Rusya, Türk boylarına karşı mücadeleyi dört yüz yıl omuzlarında taşımış olduğu gibi, Moğol kitlelerinin ilk darbelerini de yine kendisi yemiştir. Bu artık dalgaların sonuncusu olmuştur, ancak ilk darbeye göğüs geren yine Güney Rusya'dır. Güney Rusya halkının, bozkırla olan yüz yıllık savunma mücadelesinin önemi büyüktür. Türk boylarının yaşamakta oldukları bozkıra, onların günlük hayatlarına dikkatinizi yöneltirseniz, Rusya'nın bir saldırı savaşı yürütemeyeceği sonucuna ulaşırsınız. Mamafih bozkırın derinliklerine doğru yapılmış olan seferlerden hiçbir sonuç alınamamıştır. Bozguna uğrayan boylar, insan yaşayamayan bozkırın enginliğinde farklı yerlere dağılıp, çadırları ile birlikte onun derinliklerine kaçmışlardır. Onları takip etmek faydasızdı çünkü yetişmek mümkün değildi. Rus kuvvetleri - büyük şan ve şerefle seferden dönmekte, Türkler ise bozkırın derinliklerinde kuvvetlerini toplayıp tekrar Rusya'nın sınırlarına doğru hareket etmekteydiler. Uçar gibi gelen

29 Golubovskiy, a.g.e., s.33.

30 Golubovskiy, a.g.e., s.55. 
birlikler tekrar yağmalamakta, yakmakta, öldürmekte, tutsak alıp götürmekteydi. Knyazların yapmış olduğu seferlerde elde ettiklerinin, yani kendilerinin kayıplarının yüz katını elde edip dönmekteydiler. Knyazlarının bu cesurane girişimine, Rus halkının nasıl baktığını söylemek güçtür. Biz sadece yıllık yazarlarının düşüncesini bilmekteyiz ve bu da halkın sesi demek değildir. Onlar, bu seferlere dinî bir bakış açısı ile Tanrı adına, onun düşmanları olan - Tanrı tanımazların ezilmeleri için girişilen kahramanlıklar olarak bakmışlardır. ${ }^{{ }^{31}}$ Bu cümleler ile asında bozkırlıların, Rusları bir anlamda nasıl yorduklarını da anlatmaya çalışıştır.

Golubovkiy'e göre Türk boyları, Rusların tehlikeli düşmanları olmakla beraber, aynı zamanda belli bir ücret karşı̆ığında istenilen işi desteklemeye her daim hazır bir kuvveti de temsil etmekteydiler. Knyazların komşu ülkelerle yaptıkları savaşlarda onların kiralık birliklerinde yer almışlardır. Eğer rolleri Rusların haricî savaşlarına katılmakla sınırlı kalmış olsaydı, Türklerin komşuluğu Rusya'nın sadece yararına olmuş olurdu. Ancak bozkırılır, maalesef daha ziyade Rus topraklarındaki iç işlerin aktif katıımcıları olmuşlardır. Çeşitli koşulların varlığı, Türk boylarını çağırmaları konusunda Rus knyazlarını cesaretlendirmiştir. ${ }^{32}$

Ona göre "Türklerin eski tarihlerinde oynadıkları bir diğer rol, Rusya ile olan komşuluklarının başka önemli sonuçları da doğurmuş olmasıdır. Her türlü eğilimi, her daim desteklemeye hazır bir kuvvet olarak, bu halleri ile Rusya topraklarının zayıf düşmesini kolaylaştırmışlardır. Bunlarla devamlı bir mücadele yürüten, devamlı surette kendi hayatını, mallarını ve aile ocağını koruyup kollamakla meşgul, güney kültürüne ait ülkelerle eski bağlarını muhafaza etmeye çalışan Güney Rusya ahalisi ise bütün dikkatlerini buraya, güney sınırlarına yöneltmişlerdir. Onların ne etraflarına ne de Rus topraklarında meydana gelen diğer olaylara bakacak fırsat ve vakitleri olmamıştır. Güneyde herhangi bir kalıı düzen kurulması mümkün olamadığından, gücün, bozkırlılardan uzakta ve korunmuş olan kuzeyde toplanmış olması gereği açıktır. Güneyin bozkırla yürütmekte olduğu savaş gürültüsünün altında, yeni devlet fikirleri doğup güçlenebilirdi. Kuzeyin knyazları, sakin şekilde güneydeki siyasî ilişkilerin gidişatını takip edebilir ve kuvvetlerini hiçbir yere ziyan etmeksizin bütün Rusya topraklarında kendi etkilerini yaymakta kullanabilirdi. Yani kuzeydeki kuvvetler devamlı surette artmaktaydı. Türklerin tehlikeli komşuluğundan kaçan güneyliler, tarım işlerini sürdürebilecekleri daha sakin yerler aramak için çıkıp gitmek zorundalardı. Bu durum, kuzeyin knyazlarına yeni şehirler kurup aktif bir kolonizasyon politikası izleme imkânı vermiştir. Bu durumda gelirleri ve askerî kuvvetleri artmış olmalıdır. Eğer, güneydeki nüfus kuzeye doğru yönelmemiş, eski baba ocağını terk etmemiş olsaydı bile yine de kuzey ve güney arasında muazzam bir fark oluşmuş olacaktı. Yani nüfus fazlasının gidebileceği hiçbir yer yoktu. Bu yüzden insanlar kuzey yönüne doğru göç etmek zorundaydı ve duyulan can kaygısı bu hareketi daha da güçlendirmiştir". ${ }^{33}$ Bu cümleler ile yaşanılanların en büyük sebebi olarak Türk boylarını göstermektedir.

31 Golubovskiy, a.g.e., s.56-58.

32 Golubovskiy, a.g.e., s.136, 139.

33 Golubovskiy, a.g.e., s.149. 
Golubovskiy bu Türk boylarının kültürüne dair de eldeki bilgilerin azlığından şikâyet ederek kısaca şu bilgileri vermektedir: "Peçeneklerin, Uzların ve Kuman/Kıpçakların hepsi Türk'tü, hepsi bozkırlı hayat tarzı sürdürmekteydi, bu yüzden gelenek ve göreneklerinin de ortak olması gerekirdi. Bunları ta ata yurtlarından, Türkistan'dan getirmişler ve değiştirmeden muhafaza etmişlerdir. Yeni komşularının kültürü de haliyle bunlar üzerinde bir etkide bulunmuştur ancak bu etki çok da derinlere işlememiş, yüzeyden kayıp gitmiş, sadece şehirlerde yerleşen, fazla büyük olmayan Türk grupları, kendi temel millî özelliklerini yitirmiş olabilirler" dedikten sonra özellikle Bizans imparatorunun verdiği bilgileri bir değerlendirmeye tabi tutarak, başbuğların ölümünden sonra iktidarın amca çocuklarına geçtiğini, komenton adını taşıyan halk meclislerinin bulunduğunu, savaş zamanında olduğu gibi barış zamanında da bütün önemli olayların burada karara bağlandığını, bu tür meclislerde başbuğların gücü ve etkilerinin gayet önemsiz olduğunu belirtmektedir. ${ }^{34}$

Yine ona göre, komşularla devamlı savaş, içeride mücadele, Türkleri küçüklükten beri yaman savaşçılar haline getirmiştir. Hareketlerindeki çabukluk şaşkınlık vericidir. Bozkırlıların silahları; yay, omuzdan asılan ok torbası, kılıç ve kementten oluşmaktaydı. Bazıları mızrak da kullanıyordu. Yay hâkimiyetleri mükemmeldi ve herhangi bir uçan kuşu vurabilirlerdi. Başkalarından alıp benimsedikleri miğferleri de bulunmaktaydı. Gözlerinin uzağı çok iyi görebilmesi, okların hedefi tam bulmasını kolaylaştırıyordu. Herhangi bir hareketin bozkırlıların gözünden kaçması mümkün değildi. Kendi hareketleri ise, hiçbir engel önünde duraklamıyordu. Avrupalı savaş kuvvetleri için köprü ya da sallar gerekliydi. Avrupalı süvariler çözüm olarak her zaman için nehre atılmayı seçmemişlerdir. Türkler için ise bir nehri geçmek gayet kolaydı. On kadar at ya da diğer hayvan derilerini alıp, bunların kenarlarını şeritlerle dikerler, daha sonra bu torba gibi şeyin içi samanla doldurulur ve atın kuyruğuna bağlarlardı. Bu torbanın üzerine oturan Türk, atı nehre doğru sürer ve sağ salim bir şekilde karşı kıyıya ulaşırdı. Bozkırlıların başlıca zenginlik kaynağı sürüleridir. Bu hayvanlar ona yiyecek, içecek, çadırları ve giysileri için deri sağladığı gibi onun mal varlığının da esasını teşkil etmiştir. Hareketleri esnasında arkalarından sürüleri de kendilerini takip etmiştir. Yılın mevsim değişikliği dönemlerinde, büyük göçler gerçekleştirilmiştir. Daha 10. yüzyılda Peçenekler, Bizans'ın Rusya ile Hazarya ve Zihiya ${ }^{35}$ ile olan ticaretinde aracılık etmektelerdi. Korsunlularla ${ }^{36}$ karşılıklı anlaşarak onların ticarî seyahatlerinde rehberlik etmişler, ayrıca kendileri de onlara mal temin edip getirmişlerdir. Ancak bu hizmetlerinin bedeli oldukça pahalı olmuştur. ${ }^{37}$ Golubovskiy eserinde satır aralarında yerleşik Slav kültürünün bozkır kültüründen üstün olduğunu vurgulamakla birlikte savaş taktikleri, savaş aletleri gibi alanlarda bozkır kültürünün üstünlüğünü de kabul etmektedir.

34 Golubovskiy, a.g.e., s.174-175.

35 Zihiya, Zigi, Çigi: Kafkasların kuzeybatısında yer alan ve Adıge-Abhaz kavimleri birliğinin yaşadığı bölge için Antik çağlardan orta çağlara kadar kullanılan isim.

36 Kırım'da bir ticaret şehri

37 Golubovskiy, a.g.e., s.178. 
Genel olarak bakıldığında bozkırlının yaşayışının son derece mütevazı olduğunu, yiyeceklerinin esasını, et, süt ve darının oluşturduğunu, darının tarım yaparak elde ettikleri yegâne ürün olmasının muhtemel olduğunu, başarılı bir yağmadan sonra ganimetlerle dönülen kampta bunun kutlandığını, bu sırada eskilere ait bazı şarkıların Türkleri derinden etkilediğini ve yeni kahramanlıklar yapmaları için ruhlarını ateşleyerek, uçsuz bucaksız bozkırın özgürlüğüne duyduğu aşkını alevlendirdiğini ifade ederken ${ }^{38}$; Peçeneklerin dinleri konusunda hiçbir şey söylenemeyeceğini zira bu konuda o güne kadar ulaşan bilgilerin bölük pörçük ve bunlara inanmalarını sağlayacak sağlam temellerden yoksun olduklarını" kaydetmektedir. ${ }^{39}$ Ancak şunu da ifade etmektedir. "Peçenekler Avrupa'ya geldiklerinde, burada, ülkelerinde Musevilik, Müslümanlık, Hristiyanlık ve Gök-Tanrı dininin serbestçe bir arada yaşandığı Hazarlarla karşılaştılar. Müslümanlar olsun Yahudiler olsun bu yeni gelmiş olan millet üzerinde etkili olmakta gecikmediler. Bunun dışında, Türkistan ile burada İslamiyet'in uygulandığı ülkelerle olan devamlı ilişkiler, bu dinin bozkırlılar arasında da yayılmasına yol açmış olabilir ${ }^{40}$ diyerek bu konudaki görüşünü dile getirmektedir.

Kısacası Golubovskiy'in eserini yazdığı döneminde tıpkı Vasilyevskiy gibi Panslavizmin tarih çevrelerinde etkin olduğu ve tarih yazımında Hristiyanlık taassubunun önemli bir yer tuttuğu dönemde kaleme alındığı gerçeğinden hareket ettiğimizde, eserinde izlediği tarih yorumunun da bu etkilerden payını almış olduğunu görürüz. Ancak, bu yorumlamada gerek kullanmış olduğu uslûp gerek Türk boyları konusundaki yorumları dönemin bilim insanlarına göre bilimsel gerçekliğe çok daha yakın olmasına rağmen yine de zaman zaman yanlı değerlendirmelerden kaçınamamasına sebep olmuş ve tıpkı Vasilyevskiy gibi o da Peçeneklere siyasî bir teşekkül kurdurmamıştır.

Gerek Vasilyevskiy gerek Golubovskiy Peçeneklerin başbuğlarının, halkının, meclisinin, ordusunun, töre-yasalarının, bayraklarının olduğunu ve diğer devletler ile anlaşmalar yaptıklarını söyleseler de onların bir devlet veya kağanlık olarak adlandırdığımız siyasî bir teşkilatlanma kurmadıkları noktasında hemfikirdirler ki onlardan sonra Rusya'da Peçenekler konusunda çalışma yapan bütün tarihçiler bu görüşü kabul etmişlerdir. Bir devletin kurulması için ne gereklidir? Yukarıda saydıklarımız yani kağan, başbuğ, halk, toprak, töre-yasa, meclis, ordu, bayrak-sancak ve uluslararası tanınabilirlik değil midir? Bunlar olmazsa olmazlar değil midir? 0 zaman neden Peçenek boyu bir siyasî teşkilat kurmasın ki? 13 uruğ olarak Karadeniz ve Tuna sahillerinde yaşıyorlardı bunlar iç içlerinde serbest ama dış işlerinde bir araya gelip içlerinde en güçlü boyun başbuğu kim ise onun idaresi altında hareket ediyorlardı. Bu sistemi daha sonraki yıllarda uygulanan sancak veya eyalet sistemine benzetebiliriz. Ayrıca Peçenekler hakkında bilgi veren Rus, Bizans ve İslâm kaynakları başlarındaki beyleri han unvanı ile kaydetmişlerdir. Örneğin Küre Han, Turak Han gibi... Han kelimesi bilindiği üzere Türkçe'de

38 Golubovskiy, a.g.e., s.180.

39 Golubovskiy, a.g.e., s.182-183

40 Golubovskiy, a.g.e., s.184-187. 
3. yüzyıldan itibaren görülmeye başlanmış ve bağımsız yönetici anlamında kullanıımıştır. Yine kağan unvanı gibi mutlak ve evrensel bir anlam taşımıştır. ${ }^{41}$

Peçeneklerin bir devlet yani kağanlık kuramadıklarını ileri süren görüşe ilk itiraz 0. Pritsak tarafından yapılmıştır. 1975 yılında yayınladığı bir çalışmasında Peçeneklerin Rusya'da bulundukları dönem içerisinde siyasî yapılanmalarını tamamladıklarını ve merkezi (başkenti) bugün Ukrayna'nın Harkov şehri yakınlarında olan Peçenigi köyü olduğunu ileri sürerek, yönetim yapısını açıklamıştır ${ }^{42}$. Onun bu düşüncesi Peçenekler üzerine gerek Rusya'da gerekse Ukrayna'da çalışma yapan bilim insanları tarafından da desteklenmiştir. Bizde Peçenekler üzerine yaptığımız eserimizde Pritsak'ın bu görüşüne katılmakla birlikte, Tuna boylarına geldiklerinde (ki tarihler o sırada 1040-1045 arasıdır) yerleşip merkezi bugün Bulgaristan'ın Şumnu şehrine yakın bir yer olan Yüz-tepe'de kağanlıklarını kurduklarını ileri sürmekteyiz. Bu şekilde Peçenekler iki kağanlık kurmuşlardır. Biri başkenti Harkov yakınlarındaki Peçenigi köyü olan I. Peçenek Kağanlığı (895-1036) diğeri, Şumnu yakınlarındaki Yüz-tepe olan II. Peçenek Kağanlığı (1048-1091) ${ }^{43}$.
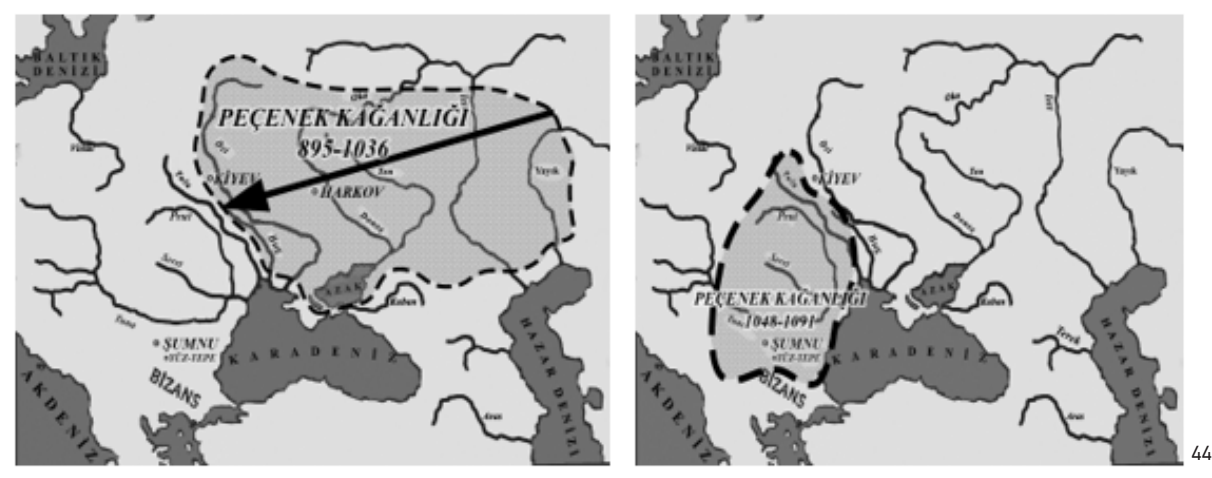

\section{Sonuç}

Rusya'da tarih yazımı I. Petro dönemi ile gelişme göstermiş ve başlangıçta Rus olmayan yabancı tarihçilere Rus milletinin tarihi emanet edilmiştir. Özellikle Bayer ve Miller gibi Alman tarihçilere yanlı bakış açıları dolayısı ile zamanla farklı bakılmış ve başını Tatişev'in çektiği yerli tarihçiler, Rus milletinin kökenini ve tarihini yabancı tarihçilerin yazmasına şiddetle karşı çıkmışlardır. Sonunda da II. Yekatarina döneminden itibaren yerli tarihçiler yetişmeye başlamıştır.

Konumuzu teşkil eden Peçenekler hakkında Rus tarihçiler genelde kendi tarihlerini yazarlarken uzun yıllar komşuluk ilişkileri kurdukları Türk boylarına dair bilgileri de eserlerinde aktarmışlardır. Karşılaştıkları başta Hazarlar olmak üzere Peçenek, Uz ve Kuman/Kıpçakları hem Türk milletinin bir parçası hem de "Bozkır Halkı" olarak görmüşler ve kendilerini de or-

41 Aydın Taneri, "Han”, DiA, C.15, s.517.

42 0. Pritsak, The Pečenegs, A case of Social and Economic Transformation, The Peter De Ridder Press 1976, s. 28.

43 Uydu Yücel, Türkistan'dan Tuna'ya Peçenekler, s. 343-360.

44 Uydu Yücel, Türkistan'dan Tuna'ya Peçenekler, s. 344, 346. 
man kavmi olarak adlandırarak, bu ilişkiyi “Ormanın-Bozkırla Mücadelesi” adı altında en ince detaylarına kadar inceleyerek anlatmışlardır. Özellikle 19. yüzyıl boyunca Kunik, Aristov vb. olmak üzere pek çok Rus tarihçi özel olarak bu Türk boylarına ait eserler yazmışlardır.

Çalışmamızın esasını 19. yüzyılın son çeyreğinde kaleme alınan iki çalışma oluşturmaktadır. Bu iki eserde o döneme kadar Peçenekler hakkında yazılan en teferruatlı eserler olma özelliğini taşımaktadırlar. Vasilyevskiy'in yazdığı “Bizans ve Peçenekler” adlı makale, Bizans'a Peçenekler tarafından yaşatılan çok zor zamanları en ince detaylarına kadar anlatmakta ve özellikle Bizans karşısında Peçenekleri daha üstün göstermektedir. İkinci eserimiz Golbovskiy'in “Moğol İstilasına Kadar Peçenekler, Uzlar ve Kuman/Kıpçaklar"dır. Bu eserde Peçeneklerin Türkistan'dan başlayarak Balkanlara kadar uzanan tarihleri anlatılmıştır. Golubovskiy, Ruslar ile mücadelelerinde genelde onların başarılı olmalarını knyazlar arasındaki iç mücadelelere bağlarken; Bizans ile olan mücadelelerini de Bizans'ın acziyet içerisinde olması ile ilişkilendirmiştir. Her ne kadar tarafsız görünmeye çalışsa da sebepleri açıklarken taraflı bir yorum yapması bu tarafsızlığına gölge düşürmektedir.

Her iki tarihçinin verdiği bilgiler birbirlerini tamamlamakla birlikte Peçenekleri bir devlet teşkilatı içerisinde göstermemeleri de dikkat çekicidir. Bunda çalışmaların yapıldığı dönemin yoğun bir Panslavizm etkisinde olmasının önemi çok büyüktür zira Peçenekler Rusların tarihi emelleri olan Karadeniz'i bir Rus denizi haline getirmelerini engellemişlerdir. Bu bakış açısı Rus tarih yazımında 1975 yılına kadar devam etmiş ancak bu yılda O. Pritsak yaptığı bir çalışmada onların devlet kurduklarını tarihi belgelerin ışığında kanıtlamıştır. Biz de 2020'de yaptığımız bir çalışma ile ona katıldığımızı belirtip ayrıca Peçeneklerin Balkanlara geldiklerinde ikinci bir kağanlık kurduklarını ileri sürmekteyiz. Bu iki kağanlıklardan birincisi Pritsak'ın ileri sürdüğü başkenti Harkov yakınlarındaki Peçenigi köyü olan I. Peçenek Kağanlığı (895-1036) diğeri bizim ileri sürdüğümüz başkenti Şumnu yakınlarındaki Yüz-tepe olan II. Peçenek Kağanlığı (1048-1091)'dır.

Peer-review: Externally peer-reviewed.

Conflict of Interest: The author has no conflict of interest to declare.

Grant Support: The author declared that this study has received no financial support.

Hakem Değerlendirmesi: Dış bağımsız.

Çıkar Çatışması: Yazar çıkar çatışması bildirmemiştir.

Finansal Destek: Yazar bu çalışma için finansal destek almadığını beyan etmiş̧tir.

\section{Bibliyografya}

Алпатов, М. А., Русская историческая мысль и Западная Евроna, (XVIII-Первая Половина XIX.в), Москва 1985 (Alpatov, M.A., Russkaya İstoriçeskaya Mısl i Zapadnaya Yevropa (XVIII-Pervaya Polovina XIX v, Moskva 1985). 
Аристов Н. А, О земле Половецкой. Исгорию-гшграфическй очеркь // Извеспя исгоримэфилологичесшго факультета Института кн. Безборода вь Нежине за 1877 г. -Юевь, 1877 (Aristov, N.A., O Zemle Polovetskoy, İstoriyu-gigrafiçeskiy Oçerk // İzvespiya isgorime-filologiçesşego fakülteta Institura kn. Bezboroda v Nejine za 1877 g. Kiyev 1877.

“Заметки об этническом составе тюркских народов" // Живая старина. Т. 6. Вып. 3-4. 1896. (Aristov, N.A., "Zametki ob Etniçeskoy sostave Turskih Narodov", Jivaya Starina, T. 6, vip. 3-4, 1896).

Бурачков П.О., Опыт исследования о куманах, или половцах // Зап. ООИД., 1877, Т.Х, с. 111-138. (PBuraçkov, P.O., Opıt Isledovaniya o Kumanah ili Polovtsah, Zap O0iD, 1877, C.X, s.111-138).

Голубовскш, П.В., Печенеги, горки и половцы до нашествш татар. История южнорусских степей 1Х-ХШ вв., Клевь, 1884. (Golubovskiy, P.G., Peçenegi, Turki i Polovtsı do Naşestvi Tatar, Istoriya Yujnorusskih Stepey IX-XIII vv, Kiyev 1884).

Fridrih Sum, İstoriç. Rassujdeniye o Patsinakah ili Peçenegah, Çiteniya v İst. Obş. İst. Drevn. Ross. 1846, No:1, s.22-24, Ç.10.

Иловайский, Д. И., История России: в 5 т.: в 7 кн. - М., 1876-1905. - Том 1. Часть 1: Киевский период, VIII, 333 c. (Illovayskiy, D.I. İstoriya Rossii, v 5 t.: v 7kn. -M., 1876-1905, Tom 1 Çast 1, Kiyevskiy Period VIII, 333c).

Карамзин, Н. М., История государства Российского. Т. 1-2. СПб., 1818-1826. (Karamzin, N.M., İstoriya gosudorstva Rossiyskogo, C. 1-2. Sank-Peterburg, 1818-1826.).

Куник А., О торкских печенегах и половцах по венгерским источникам // Зап. Академии наук. СПб., 1854. Отд. I, III. (Kunik, A.O., O Torkskih Peçenegah i Polovtsah po Vengerskih İstoçnikam, Zap Akademii Nauk Sank-Peterburg, 1854, Otd. I, III).

томаров, Н.И., Черты народной южнорусской истории // Исторические монографии и исследования. T. 1. СПб, 1903 (Kostomarov, N.I.., Çertı Narodnoy Yujnorusskoy İstorii // İstoriçeskiye Monografii i İsledovaniya, C.1, Sank-Peterburg 1903).

Костомаров Н. И., История России в жизнеописаниях ее главнейших деятелей: Т. 1-3. - СанктПетербург, 1915. - T. 1. (Kostomarov, N.I., İstoriya Rossi v Jizneopisaniyah yiyo Glavşeynıh Deyateley, C.1., Sank-Peterburg).

Pritsak, O., The Pečenegs, A case of Social and Economic Transformation, The Peter De Ridder Press 1976.

Соловьев, С.М., Истории России с древнейших времён, С.І, Москва 1851 (Solovyev, S.M., Istoriya Rossii s Drevneyşıh Vremyon, C.I, Moskva 1851).

Васильевский В.Г., “Византия и печенега “Труды. -СПб., 2010 (Vasilyevskiy, G.V., Vizantiya i Peçenega”, Trud, Sank-Peterburg 2010).

Uydu Yücel, M., “Rusya İmparatorluğu Tarih Yazımında Haçıı Seferleri”, I.Ü. Tarih Dergisi, S.66, 2017/2, s.15-34.

Uydu Yücel, M., Türkistan'dan Tuna'ya Peçenekler, İstanbul, Doğu Kütüphanesi Yayınları, İstanbul 2020. Taneri, A., “Han”, DiA, C.15, s.517-18.

Устрялов, Н. Г., Русская история, в 2 ч., СПб., 1855 (Ustryalov, N.G., Russkaya İstoriya, в 2 ч., SankPeterburg, 1855). 
